\title{
LAST RITES AND HUMAN RIGHTS: FUNERAL PYRES AND RELIGIOUS FREEDOM IN THE UNITED KINGDOM
}

\author{
PETER CUMPER, University of Leicester \\ TOM LEWIS, Nottingham Trent University ${ }^{*}$
}

This article considers the litigation in Ghai v Newcastle City Council in which the legality of open air funeral pyres under the Cremation Act 1902, and under the right to freedom of religion and belief in article 9 of the European Convention on Human Rights, was considered. Ultimately the Court of Appeal held that open air funeral pyres within a walled enclosure were not unlawful. But at first instance the Administrative Court, which had assumed that domestic law prohibited such pyres, had held that such a ban would not breach article 9 since it was legitimate to prevent causing offence to the majority of the population. It is the approach of the Administrative Court to article 9 (which was not considered by the Court of Appeal) that forms the basis of the critical analysis in this article. In particular it is argued that the Administrative Court undervalued the right to freedom of religion and belief, as against the need to prevent offence to others, and adopted a stance which was overly deferential to Government and Parliament.

\section{INTRODUCTION}

The rituals that surround the disposal of the dead are one of our species' defining characteristics. ${ }^{1}$ As well as the very practical need of having to dispose of a lifeless corpse, death rituals tend to serve many other functions. ${ }^{2}$ These range from commemorating the

\footnotetext{
* The initial version of this article analysed the decision of the Administrative Court in Ghai. However, after submission and acceptance of the article, the Court of Appeal upheld Mr Ghai's appeal, though on much narrower grounds, and without needing to consider Administrative Court's approach to article 9 ECHR. At a late stage in the publication process we have endeavoured to incorporate the essence of the Court of Appeal's decision into the text, but the thrust of the article remains a critique of the Administrative Court's approach to the article 9 issues in the case, which remains of interest to scholars of human rights and religion. We should like to thank Graham Ferris and an anonymous reviewer for their helpful comments on the earlier draft. Errors and omissions remain our own.

${ }^{1}$ See Theya Molleson, 'The Archaeology and Anthropology and of Death: what the bones tell us', in Sally C Humphreys and Helen King (eds) Mortality and Immortality: the anthropology and archaeology of death (Academic Press, London, 1981) p 15; and Peter J Ucko, 'Ethnography and Archaeological Interpretation of Funerary Remains' (1969) World Archaeology, 1(2) pp 262-280.

${ }^{2}$ On the different ways by which bodies can be disposed see DJ Davies, 'Forms of Disposal', in K Garces-Foley (ed) Death and Religion in a Changing World (ME Sharp Press, NY, 2005) pp 228-245.
} 
passing of a human life and facilitating public expressions of grief, ${ }^{3}$ to impacting upon group identity, ${ }^{4}$ and demonstrating a belief in an afterlife. ${ }^{5}$ Yet whilst disposal of the dead has, from time immemorial, been a universal problem, the way in which humans have traditionally gone about this task has differed considerably. ${ }^{6}$ As a consequence, from Egyptian mummies and Indian cremations to Eastern ancestor rites and African sacrificial ceremonies, every culture has its own set of traditions that are synonymous with death. ${ }^{7}$

The fact that rituals surrounding death tend to be a paradigm exemplar of religious and cultural difference, should perhaps come as no great surprise. In death, as in life, the traditions of every culture are diverse, moulded by a variety of social, political, religious and environmental factors. ${ }^{8}$ Yet the emotive nature of death perhaps explains why religious belief is such a powerful influence in shaping the way in which every culture views death. ${ }^{9}$

Accordingly, it is hardly a shock to discover that there are many important differences between Christian funerary rites, ${ }^{10}$ and those found within the Buddhist, ${ }^{11}$ Hindu, ${ }^{12}$ Jewish, ${ }^{13}$ Islamic ${ }^{14}$ or $\mathrm{Sikh}^{15}$ traditions.

Perhaps mindful of such considerations the eminent English anthropologist, William HR Rivers, once observed that '[f]ew customs of mankind take so firm a hold of his

\footnotetext{
${ }^{3}$ See Mary Bradbury, Representations of death: a social psychological perspective (Routledge, 1999); and Jeanne Katz, Jenny Hockey, and Neil Small (eds) Grief, Mourning and Death Ritual: Facing Death (Open University Press, 2001).

${ }^{4}$ See R Grainger, 'Let Death be Death: Lessons from the Irish Wake', (1998) Mortality, 3(2), pp 129-141.

${ }^{5}$ See D J Davies, The Theology of Death (T\&T Clark, London, 2008); and DJ Davies, Death, Religion and Belief. The Rhetoric of Funerary Rites (Continuum International, London, 1997).

${ }^{6}$ See Mike Parker Pearson, The Archaeology of Death and Burial (Sutton Publishing, Stroud, 2003); and Peter Metcalf, Celebrations of Death. The Anthropology of Mortuary Ritual (CUP, Cambridge, 1991).

${ }^{7}$ See Antonius CGM Robben (ed) Death, Mourning and Burial: a cross cultural reader (Blackwell, Oxford 2004); and Allan Kellehear, Glennys Howarth, and Kathy Charmaz (eds) The Unknown Country: Death in Australia, Britain and the USA (MacMillan, Hampshire, 1997).

${ }^{8}$ See HC Triandis, Culture and Social Behavior (McGraw-Hill, NY, 1994); and Ronald Inglehart, Modernization and Postmodernization: Cultural, Economic, and Political Change in 43 Societies (Princeton University Press, Princeton, 1997).

${ }^{9}$ See Kenneth Kramer, The Sacred Art of Dying: How the World Religions Understand Death (Paulist Press, 1988).

${ }^{10}$ Differences also exist within the different Christian traditions on death rites. See Lizette Larson-Miller, 'Roman Catholic, Anglican and Eastern Orthodox Approaches to Death', in Kathleen Garces-Foley, note 2, above, at pp 93-121.

${ }^{11}$ See Rita Langer, Buddhist Rituals of Death and Rebirth Contemporary Sri Lankan Practice and Its Origins (Routledge, 2007).

${ }^{12}$ See Pittu Laungani, 'Death Among Hindus in India and England' (1999) Journal International Journal of Group Tensions, 28(1-2), 85-114.

${ }^{13}$ Ivan G Marcus, The Jewish Life Cycle. Rites of Passage from Biblical to Modern Times (University of Washington Press, 2004), pp 193-248.

${ }^{14}$ See N Dessing, Rituals of Birth, Circumcision, Marriage, and Death Among Muslims in the Netherlands, (Peeters, Leuven, 2001), pp 141-182.

${ }^{15}$ See Kristina Myrvold 'Sikhism and Death' in Kathleen Garces-Foley, note 2, above, at pp 178-206.
} 
imagination as his modes of disposing of the bodies of his dead'. ${ }^{16}$ Yet whilst these words convey a seemingly immutable truth, British social attitudes to death and related funeral rites have changed significantly in the century since Rivers published his work. For example, today, crematoria are found in practically every town, due to the fact that a majority of British people choose to be cremated in such places after death. But it was not always so. Less than two hundred years ago burial of the dead, rather then cremation, was the norm in Britain. ${ }^{17}$ Accordingly, from the period when legal restrictions on cremation were lifted (from 18521884), to its ultimate 'popularisation' (since 1952), the British public's approach to cremation has shifted dramatically. ${ }^{18}$ As a consequence, when a person dies today in Britain it is the norm for their body (having been prepared by an undertaker) to be kept in a closed coffin, immediately prior to its disposal in a crematorium.

But what if a person wishes that their body after death be neither cremated in a crematorium nor be interred in the ground? What if such a request is (in their opinion) mandated by their religion or culture? Is there a human right to dispose of the body of the deceased even if it is done in a way that is at odds with existing social norms or might even cause offence to others? How far does contemporary Britain, which places great store by respecting racial and religious diversity in life, accord respect to such matters in death?

Such matters are not merely sterile matters of academic conjecture. On the contrary, they have recently been considered by the British Courts. In Ghai v Newcastle City Council, ${ }^{19}$ the Administrative Court held that an (apparent) statutory ban preventing a Hindu man, Davender Ghai, having his remains cremated on an open air funeral pyre, in accordance with his belief that this was the only way in which the cycle of birth and rebirth could progress, was not in breach of his right to freedom of religion and belief under article 9 of the European Convention on Human Rights (ECHR). It was justifiable, the Administrative Court held, for the state to prohibit open air cremation in order to prevent offence being caused to those in the United Kingdom who would object to this practice. The Court of Appeal subsequently upheld Mr Ghai's appeal but not on the basis that his article 9 rights had been breached.

\footnotetext{
${ }^{16}$ WHR Rivers, 'The Contact of Peoples', in Essays and Studies presented to William Ridgeway (1913), pp 474-492, cited by AL Kroeber in (1927) American Anthropologist 29(3) 308-315 at 309.

${ }^{17}$ See Peter C Jupp, From dust to ashes: the replacement of burial by cremation in England 1840-1967 (Congregational Memorial Hall Trust, 1990); and Glennys Howarth and Peter C Jupp (eds), The Changing Face of Death: Historical Accounts of Death and Disposal (Palgrave Macmillan, 1997).

${ }^{18}$ See Peter C Jupp and Tony Walter, 'The Healthy Society 1918-1998', in Peter C Jupp and Clare Gittings (eds) Death in England. An Illustrated History (Manchester University Press, 1999) pp 256-282; and Peter C Jupp, From dust to ashes: cremation and the British way of death (Palgrave Macmillan, 2006).

${ }^{19}$ R (Ghai) v Newcastle City Council (Ramgharia Gurdwara, Hitchin and another intervening) [2009] EWHC 978 (Admin); [2009] WLR (D) 151.
} 
Rather, it held that the kind of cremation acceptable to Mr Ghai's beliefs (funeral pyre cremation within a roofless walled enclosure) was not contrary to English law after all. ${ }^{20}$ The Court of Appeal, since it was able to dispose of the issue using the traditional canons of statutory interpretation, did not need to consider human rights issues that had been addressed by the Administrative Court. Notwithstanding this successful appeal, this article analyses the Administrative Court's approach to the article 9 issues raised in Ghai, which remain untouched by the Court of Appeal's decision. It questions the reasoning of Cranston J in a number of respects, and attacks the Administrative Court for having taken what it regards as an overly conservative approach to the application of article 9. It concludes by pointing out some ironic consequences highlighted by the litigation, concerning the protection of religious freedom under the Human Rights Act 1998

\section{THE LAW ON CREMATION AND GHAI V NEWCASTLE CITY COUNCIL}

Davender Ghai, an orthodox Hindu, believed that in order to achieve a 'good death' and successful passage to the afterlife, his remains needed to be cremated on an outdoor funeral pyre, a Vedic rite known as the anthyesthi sanskara. Anything less would have 'devastating effects for him in the afterlife', interrupting his cycle of birth and rebirth, possibly irreparably. ${ }^{21}$ Newcastle City Council refused his request, maintaining that UK law prohibited open air cremation. Mr Ghai sought a judicial review of that decision, claiming a breach of article 9 of the ECHR. The Secretary of State for Justice (the Minister responsible for cremation law), as well as a Sikh temple and an organisation advocating natural burial methods, all made representations in their capacities (respectively) as an interested party and first and second interveners.

The law concerning cremation that was applicable in Ghai is contained in the Cremation Act 1902. 'Crematorium' is defined as '... any building fitted with appliances for the purpose of burning human remains'. ${ }^{22}$ The Secretary of State is empowered to make regulations concerning the conditions for burning human remains, ${ }^{23}$ and it an offence to knowingly carry out the burning of human remains except in accordance with the

\footnotetext{
${ }^{20}$ R (Ghai) v Newcastle City Council (Ramgharia Gurdwara, Hitchin and another intervening) [2010] EWCA Civ 59.

${ }^{21}$ Ibid, at [8].

${ }^{22}$ The Cremation Act 1902, section 2. Section 4 enables local authorities to establish crematoria and section 5 regulates their location in relation to dwellings and public highways and consecrated ground.

${ }^{23}$ Ibid, section 7.
} 
regulations. ${ }^{24}$ The most recent regulations are the Crematorium (England and Wales)

Regulations 2008, which define cremation as the 'burning of human remains', and they provide that no cremation may take place except in a crematorium the opening of which has been notified to the Secretary of State. ${ }^{25}$

Having lost at first instance (see below) Mr Ghai appealed to the Court of Appeal which heard representations that his religious belief would be satisfied if his funeral pyre was located within a walled structure, as long as it was possible for sunlight to shine directly on the body during cremation. ${ }^{26}$ This clarification of the appellant's position led to the Court of Appeal giving the term 'building' in section 2 of the Cremation Act its 'natural and relatively wide meaning' so as to encompass this kind of structure. ${ }^{27}$ As a result this kind of open air cremation was found not to be unlawful; and consequently no human rights issues fell to be considered by the Court of Appeal. ${ }^{28}$

At the Administrative Court Cranston $\mathrm{J}$ had held, based upon the understanding that a fully open cremation was required by Mr Ghai's beliefs, that the combined effect of the legislation and the regulations was plain: that 'the burning of human remains, other than in a building, such as on an open air pyre, [was] an offence'. ${ }^{29}$ He therefore went on to analyse whether the (supposed) legislative ban on funeral pyre cremation constituted a breach of article 9 of the ECHR. ${ }^{30}$ It is to this analysis to which the remainder of this article now turns.

The European Court of Human Rights has repeatedly affirmed the importance of freedom of thought, conscience and religion as being 'one of the foundations of a democratic society [and] one of the most vital elements that go to make up the identity of believers and

\footnotetext{
${ }^{24}$ Ibid, section 8 .

${ }^{25}$ See SI 2008, No 2841, reg 13.

${ }^{26}$ See note 20, above, at [3] (Lord Neuberger MR). Moore-Bick LJ and Etherton LJ agreed, giving no separate judgments.

${ }^{27}$ Ibid, at [35] (Lord Neuberger MR).

${ }^{28}$ Ibid, at [40] (Lord Neuberger MR).

${ }^{29}$ See note 19, above, at [83]. On Cranston J's reasoning see also [79-85]. The Administrative Court operated on the understanding that the requirement be that cremation take place fully in the open, ie not within any structure (see note 19 at[8-9]); and that 'building' meant a 'structure with roof and walls' (see note 19 at [82]). The possibility of compromise, a walled enclosure open to the sun, seems not to have been explored at first instance. The Court of Appeal noted that this was not surprising given the content of the pre-action correspondence (see note 20 at [2].)

${ }^{30}$ Article 9 of the ECHR provides that:

(1) Everyone has the right to freedom of thought, conscience and religion; this right includes freedom to change his religion or belief and freedom, either alone or in community with others and in public or private, to manifest his religion or belief, in worship, teaching, practice and observance.

(2) Freedom to manifest one's religion or beliefs shall be subject only to such limitations as are prescribed by law, necessary in a democratic society in the interests of public safety, for the protection of public order, health or morals, or for the protection of the rights and freedoms of others.

It was also claimed that the ban breached articles 8 (the right to respect for a private life) and 14 (the principle of non-discrimination) of the ECHR.
} 
their conception of the good life [as well as being] a precious asset for atheists, agnostics, sceptics and the unconcerned. ${ }^{31}$ Article 9 protects, in absolute terms, one's freedom of thought, conscience and religion. Thus, a person can believe whatever they want, with the state lacking any power to interfere with this internal sphere, the forum internum. In contrast, however, the manifestation of religion or belief may be subject to the imposition of restrictions by the state as long as such restrictions are in accordance with the three criteria under article 9(2) - 'prescribed by law', in pursuance of one of the legitimate aims listed, and 'necessary in a democratic society,' with this last requirement meaning that any restriction must be proportionate to the aim that the state is claiming to protect. ${ }^{32}$

In conducting the article 9 analysis, Cranston $\mathrm{J}$ addressed a series of questions set out by the House of Lords in $R$ (Williamson) $v$ Secretary of State for the Home Department. ${ }^{33}$ First, were the claimant's beliefs religious? In answering this question in the affirmative, the Court held that they 'clearly' were. ${ }^{34}$ Secondly, was athyesthi sanskara a manifestation of a genuine belief held in good faith? The Court held that it was, ${ }^{35}$ for while certain 'minimum thresholds relating to seriousness, coherence and conformity' had to be satisfied, ${ }^{36}$ and it was a question for the court to decide whether open air cremation was an essential belief of one strand of orthodox Hinduism, it was 'emphatically not for the court to embark on an inquiry as to the validity of a belief by some standard such as a religious text or whether it conforms or differs from that of others professing the same religion'. ${ }^{37}$ Furthermore, Cranston $\mathrm{J}$ reasoned that whilst the belief must be:

... coherent in the sense of being intelligible and capable of being understood ... too much should not be demanded in this regard. Typically religion involves belief in the supernatural. It is not always susceptible to lucid exposition or, still less, rational justification. The language used is often the language of allegory, symbol and metaphor. Depending on the subject matter, individuals cannot always be expected to express themselves with cogency and precision. ${ }^{38}$

\footnotetext{
${ }^{31}$ Kokkinakis v Greece (1993) 17 EHRR 397.

${ }^{32}$ See Handyside v UK (1981) 4 EHRR 149 at [49].

${ }^{33} \mathrm{R}$ (on the application of Williamson) v Secretary of State for Education and Employment [2005] 2 AC 246.

${ }^{34}$ See note 19 , above, at [86].

${ }^{35}$ Ibid, at [101].

${ }^{36}$ Ibid, at [87].

${ }^{37}$ In regard to open air cremation, a great deal of conflicting expert evidence was adduced by both sides in relation to Hindu funerary beliefs and customs. See note 19, above, at [21-45].

${ }^{38}$ See Williamson, at [23] (Lord Nicholls), cited at [88] in Ghai.
} 
The Court noted that the position was, however, different for Sikhs. The first intervener, a Sikh Gurdwara, did not claim that open air cremation was a matter of 'doctrine and dogma', but was rather a 'traditional practice' advocated by the Sikh Code of Conduct. In view of the fact that Christians and Muslims had burial grounds allocated to them, it was argued that Sikhs should also have their practices recognised. ${ }^{39}$ However, Cranston J held that since open air pyres were only a 'matter of tradition for Sikhs in India' rather than a tenet of 'dogma and belief', article 9 accorded them no protection on this issue. ${ }^{40}$

What was beyond dispute in this case (at first instance) was that by placing curbs on the burning of human remains, the 1902 Act and the 2008 Regulations clearly constituted an interference with the manifestation of a person's belief, contrary to article 9(1) of the ECHR. Accordingly, the next question which had to be answered was whether such a restriction could be justified under article 9(2), as pursuing a legitimate aim in a proportionate manner.

The Secretary of State had originally argued that the 'legitimate aim' which justified banning open air funeral pyres lay in the need to prevent risks to the environment and threats to the safety of bystanders, due to the release of dioxins, mercury emissions and polycyclic aromatic hydrocarbons. However, these public health and environmental arguments were abandoned once it was accepted that such concerns could be dealt with through regulation. ${ }^{41}$ Instead, the Secretary of State proceeded to argue that the ban was justifiable on the basis that it pursued the legitimate aim of protecting public morals and the rights of others, since 'a large proportion of the population of this country would be upset and offended by open air funeral pyres and would find it abhorrent that human remains were being burned in this manner'. ${ }^{42}$

The Administrative Court accepted that protecting public morals and the rights of others was indeed a legitimate aim of the ban; but it had next to consider whether the ban constituted a proportionate interference in pursuit of that aim - ie, did the requirement that cremation take place in a building strike a 'fair balance' between the rights of the claimant and the interests of society? ${ }^{43}$ Cranston J, having taken into account various 'backdrop features' (discussed in part 3 below), and declaring that he intended 'now [to] meet the

\footnotetext{
${ }^{39}$ Note 19 , above, at [16].

${ }^{40}$ Ibid, at [102].

${ }^{41}$ Ibid, at [61] and [105].

42 Ibid.

${ }^{43}$ Huang v Secretary of State for the Home Department [2007] 2 WLR 581 at [19] (Lord Bingham).
} 
central issue head on', ${ }^{44}$ held that the prohibition did not breach article 9 because the Secretary of State was entitled to conclude:

... that the present legislative framework [was] consistent with mainstream cultural expectations of persons living in this country and secure[d] in a practical way the avoidance of likely offence and distress. That calculation [was] not one on which a judge c[ould] speak with any great expertise or authority. The resolution of the various competing interests on this difficult and delicate issue by elected representatives [was] not one a court should easily set aside. It [was] within the remit of the Secretary of State to conclude ... that a significant number of people would find both the principle and the reality of cremation by means of open air pyres to be a matter of offence. ${ }^{45}$

As a result, Cranston $\mathrm{J}$ concluded that the claimant, in relation to his article 9 claim, should '[p]ursue his cause in the public sphere, by campaigning, lobbying and the use of other avenues open to him in a democratic society to try to effect a change in the legislative framework. ${ }^{46}$

\section{A CRITIQUE OF THE 'BACKDROP FEATURES'}

According to Cranston J, several features in this case formed a 'backdrop' to the Administrative Court's decision to deny Mr Ghai an open air cremation. Yet whilst these factors were referred to as 'backdrop features', we suggest that in reality their enumeration by Cranston $\mathbf{J}$ was the proportionality analysis in this case. After all, this was the only point in his judgment at which the competing interests were balanced against each other-and it was immediately thereafter (and without any further analysis) that Cranston $\mathrm{J}$ held the matter of open air cremations should essentially be a decision for Government and Parliament rather

\footnotetext{
${ }^{44}$ Note 19 , above, at [121].

${ }^{45}$ Ibid, at [122].

${ }^{46}$ Ibid, at [123]. There was also found to be no breach of article 8 of the ECHR due, inter alia, to the 'public character' of open air cremation [138] and that such cremations were not so fundamental to the lives of Hindus and Sikhs in the UK as to form part of their identity [139]. Similarly, article 14 of the ECHR was not engaged because there was an 'objective and reasonable justification' for the difference in treatment with regard to UK rules governing funeral rites [147-151].
} 
than a court. ${ }^{47}$ Given that these backdrop features underpin the determination of the article 9 issue in this case, they warrant a more detailed analysis.

\section{i) No blanket interference with the claimant's article 9 rights}

The first backdrop feature noted was that there had been 'no blanket interference with the claimant's article 9 rights' ... 'as an orthodox Hindu [he] ha[d] a very wide freedom in this country to manifest his religious beliefs [and that] in effect the only interference he complain[ed] of [was] the requirement that his funeral take place in a building' ${ }^{48}$

This, with respect, rather misses the point: all that Davender Ghai sought was the right to an open air cremation. The fact that he could still manifest his belief in any number of other ways was of little relevance to his central contention (which the Court accepted was held in good faith), that his failure to perform the rite of anthyesthi sanskara would 'have devastating effects for him in the afterlife'. ${ }^{49}$ For Mr Ghai, denial of this particular ceremony would mean that proper performance of all his other religious duties (which were not interfered with) would count for nought. Accordingly, for the Court to suggest that Mr Ghai remained free to do other things required by his belief seems hardly relevant to his central claim that it was restriction of this 'pivotal' sacrament that breached his article 9 rights.

\section{ii) The majority of Hindus do not consider open air cremation to be essential}

The second backdrop factor considered by Cranston J was 'that the vast majority of Hindus in this country do not consider that cremation on an open air pyre is essential to discharge their religious obligations ${ }^{50}$ Such reasoning brings to mind previous case law of the European Court $^{51}$ and (previously) Commission ${ }^{52}$ of Human Rights in Strasbourg, whereby a religious practice must be deemed 'necessary' for it to come within article 9(1) of the ECHR. ${ }^{53}$ By

\footnotetext{
${ }^{47}$ Ibid, at [161].

${ }^{48}$ Ibid, at [116].

${ }^{49}$ Ibid, at [8].

${ }^{50}$ Ibid, at [117]. On Hindu attitudes to death generally see Pittu Laungani, 'Death Among Hindus in India and England' (1999) Journal International Journal of Group Tensions, 28(1-2), pp 85-114; and Shirley Firth, Dying, Death and Bereavement in a British Hindu Community (Peeters, Leuven, 1997).

${ }^{51}$ For example, when a Jehovah's Witness refused to attend a parade in her school commemorating war with Italy, the European Court was unable to discern anything 'either in the purpose of the parade or in the arrangements for it, which could offend the applicant's pacifist convictions': Valsamis v Greece, (1997) 24 EHRR 294 at [32], (18 December 1996).

${ }^{52}$ In X v Austria, Application No 1753/63, 8 European Yearbook 174, the Commission denied a prisoner access to a prayer chain on the ground that it was not 'an indispensable element in the proper exercise of the Buddhist religion'.

${ }^{53}$ It is important to note that in recent years the European Court has tended to move away from this approach, and in Hasan and Chaush v Bulgaria (2000) 10 BHRC 846 at [78], (26 October 2000), it held that article 9 of the
} 
focusing on the manifestation of a religion or belief rather than its motivation, ${ }^{54}$ this approach has the advantage of excluding bogus or trivial beliefs from article $9(1)^{55}-$ yet it also comes close to adjudicating on whether a particular practice is formally required by a religion, a task which judges (given the relevant theological issues) appear ill-equipped to handle. Moreover, this approach is typically based on the questionable assumption that every religion has a single clearly discernable text, which is not open to different interpretations. Thus, in Ghai, the extent to which the Court should have taken into account the views of most Hindus on the matter of open air funeral pyres is questionable. From the Pilgrim Fathers to the Universal Declaration on Human Rights (1948), religious freedom has been predicated on the assumption that a believer has the right to depart from the majority view and act according to his/her beliefs. Indeed, it is only because of the existence of a wide range of world views (including atypical ones) that rules exist (both nationally and internationally) governing freedom of religion and belief —were it were otherwise, such legal provisions would surely be unnecessary.

It is important to bear in mind that, at an earlier stage in its analysis, when considering whether anthyesthi sanskara was an 'essential belief of one strand of orthodox Hinduism', the Court acknowledged that the fact that the 'great majority of Hindus in the United Kingdom do not share the claimant's belief [was] not a complete answer' ${ }^{56}$ Thus, having apparently, and (it is submitted) rightly, minimised the importance of the relevance of majority beliefs when assessing whether open air cremation was a core aspect of Hindu belief, it is perhaps surprising that this issue re-emerged as part of the 'backdrop' to the proportionality analysis.

\section{(iii) Cremation law is outdated}

The third backdrop factor related to Ghai's submission that the law was outdated because the legal definition of a crematorium (ie, a 'building fitted with appliances for the purpose of burning human remains') dated back to 1902, and that 'the balance it struck could no longer be regarded as valid'. ${ }^{57}$ With this in mind Cranston $\mathrm{J}$ suggested that there was 'no significant

Convention 'excludes any discretion on the part of the State to determine whether religious beliefs ... are legitimate'.

${ }^{54}$ See Arrowsmith v UK, Application No 7050/75, 19 DR 5, 19.

${ }^{55}$ For example, see United States v Kuch, 288 F Supp 439 (DDC 1968), where the Defendant, having been charged with a number of drugs offences, argued unsuccessfully that her arrest violated the free exercise of her (alleged) religion, central tenets of which included venerating a three-eyed toad and singing the supposedly 'holy' songs, 'Puff, the Magic Dragon' and 'Row, Row, Row Your Boat.'

${ }^{56}$ Note 19 , above, at [100].

${ }^{57}$ Ibid, at [118]. 
evidence that on the disposal of human remains any significant cultural change ha[d] occurred since then. ${ }^{58}$ Furthermore, in rejecting Ghai's argument, he noted that the 2008 Cremation Regulations had been subject to public consultation, and that faith groups (including the Hindu Forum of Britain), had been sent copies of the Consultation paper. ${ }^{59}$

Hindu and other religious groups may indeed have been consulted in relation to cremation practices, but the contention that cultural expectations on any issue have not changed since the Edwardian age is surely doubtful. ${ }^{60}$ The last century has witnessed the transformation of Britain from a (predominantly) ethnically and religiously homogenous nation into a racially and religiously diverse society. ${ }^{61}$ Indeed, much has already been written on how British attitudes, practices and beliefs about death have undergone significant change in recent decades. ${ }^{62}$ Thus, any assumption that cultural norms governing the disposal of the dead are as they were in 1902 is extremely questionable. After all, there have been significant changes in relation to the practice of cremation, not least in relation to the fact that in 1960 less than one in three corpses were cremated, whereas today more than 70 per cent of deaths lead to cremations in Britain. ${ }^{63}$ Furthermore, with regard to the 2008 Regulations, it should be noted that the Government consultation paper which preceded them, stated that:

We recognise that some faiths would prefer to cremate the remains of a member of that faith on what is known as a funeral pyre. Any question as to whether the regulations permit funeral pyres is a matter for the courts and outside the scope of these regulations. ${ }^{64}$

\footnotetext{
58 Ibid.

${ }^{59}$ Cremation regulations, Consolidation and Modernisation, CP 11/07, 16 July 2007, available at <http://webarchive.nationalarchives.gov.uk/+/http://www.justice.gov.uk/docs/cp1107.pdf> (accessed 4 January 2010).

${ }^{60}$ On the specific issue of Hindu cremation see, S Firth, 'Changing Hindu attitudes to cremation in the UK', (2003) Bereavement Care, 22(2), at 25-28.

${ }^{61}$ For example, the 2001 census for England and Wales illustrates, graphically, the religiously diverse nature of the UK today. See <http://www.statistics.gov.uk/census2001/profiles/commentaries/ethnicity.asp> (accessed 4 January 2010).

${ }^{62}$ For example see, Kathleen Garces-Foley (ed), Death and Religion in a Changing World (ME Sharpe, New York, 2005); Allan Kellehear, Glennys Howarth, and Kathy Charmaz (eds) The Unknown Country: Death in Australia, Britain and the USA (MacMillan, 1997); Peter Jupp, Clare Gittings (eds) Death in England. An Illustrated History (Manchester University Press, 1999); and DJ Davies, A Brief History of Death (Blackwell, Oxford, 2004).

${ }^{63}$ See PC Jupp, From dust to ashes: cremation and the British way of death (Palgrave Macmillan, 2006).

${ }^{64}$ Cremation regulations, Consolidation and Modernisation, CP 11/07, 16 July 2007, available at <http://webarchive.nationalarchives.gov.uk/+/http://www.justice.gov.uk/docs/cp1107.pdf> (accessed 4 January 2010).
} 
This certainly would appear to be some kind of (tacit) acknowledgment, by the Government at any rate, that there have indeed been significant cultural changes in this area.

\section{(iv) An absence of any European consensus on funeral pyres}

The fourth backdrop factor identified by Cranston $\mathrm{J}$ was the absence of any European consensus on the issue of funeral pyres. According to the evidence adduced by the Secretary of State, 'no other Council of Europe state ... indicated that it permitted funeral pyres', while the embassies of twelve Council of Europe states confirmed that they did not permit them. Thus, material such as this 'provided support for the conclusion that the [prohibition on funeral pyres was] proportionate and lawful'. ${ }^{65}$

In view of the historical influence of Christianity in Europe, a faith which (until comparatively recently) has viewed cremation in negative terms, ${ }^{66}$ it is perhaps unsurprising that other European nations do not permit funeral pyres. ${ }^{67}$ This is especially so given that most other European countries have relatively small Hindu populations, particularly in comparison with the sizeable numbers of Hindus living in the UK. Yet, there is perhaps a more fundamental objection to Cranston J's decision to identify this particular issue as a backdrop factor. It is difficult to see why the absence of a consensus across Europe should be one of the factors leading to a finding by a domestic court that such a ban is proportionate in the United Kingdom.

The fact that it is 'not possible to discern throughout Europe a uniform conception of the significance of religion in society' is certainly something that the European Court of Human Rights takes into account when it chooses to afford states a widened margin of appreciation in cases involving religion. ${ }^{68}$ But the issue of funeral pyres has not (as yet) been litigated before the Strasbourg Court. Accordingly, there is no case law on the subject which, by virtue of section 2 of the Human Rights Act 1998, must be 'taken into account' by UK

\footnotetext{
${ }^{65}$ Note 19, above, at [119]. Some support for this argument may be found in the dicta of Lord Hoffmann in R (Begum) v Headteacher and Governors of Denbigh High School [2005] 2 All ER 396 at [64].

${ }^{66}$ See JS Curl, The Victorian celebration of Death (Sutton Publishing Ltd, Stroud, 2000) p179; and C Quigley, The corpse; a history (McFarlane, North Carolina, 1963) p102.

${ }^{67}$ For example, the change in the Catholic approach has been summarised as follows: 'Since 1963 the Church has given permission for Catholics to be cremated. Prior to this cremation was seen to be anti-Christian in intention'. See The Guidance Note on the Burial of Ashes, to the Bishops conference of England and Wales, Department for Christian Life and Worship (2008), available at <http://www.liturgyoffice.org.uk/Resources/OCF/Ashes.pdf> (accessed 4 January 2010).

${ }^{68}$ See, for example, Şahin v Turkey (2007) 44 EHRR 5 at [109]; Otto Preminger Institute v Austria (1994) 19 EHRR 34 at [50]; and Murphy v Ireland (2004) 38 EHRR 13 at [67]. This justification proffered by the Strasbourg Court has been subjected to criticism. See eg, T Lewis 'What not to wear: religious rights, the European Court, and the margin of appreciation' (2007) 56 ICLQ, 395.
} 
courts. ${ }^{69}$ The Ghai court, by adopting one aspect of the Strasbourg Court's methodology (which is very much a product of that court's supra-national character), was necessarily tending towards a 'lowest European common denominator' approach. Such an approach will inevitably lead to a dilution of protection for the right to manifest one's religious belief in the UK. It is surely questionable whether it is appropriate for a national court to count this as one of the factors contributing to its own deferential stance on the question of proportionality. ${ }^{70}$

\section{v) Open air cremation could cause offence}

The final and, perhaps, most troubling backdrop feature in Ghai relates to the 'legitimate aim' criterion relied on by the Secretary of State for the prohibition of funeral pyres. This was the view that 'a large proportion of the population of this country would be upset and offended by open air funeral pyres and would find it abhorrent that human remains were being burned in this manner'. ${ }^{71}$ While the Secretary of the State will doubtlessly have reflected the views of some, his reasoning can be criticised on the basis that it is questionable whether the proscription of otherwise harmless conduct can ever be justified merely on the grounds that it may cause offence. ${ }^{72}$ At the very least there are serious difficulties in assessing whether the (subjective) intensity of perceived offence is sufficient to justify a criminal sanction, because what one person finds offensive 'may be water off a duck's back to another'. ${ }^{73}$ As Joel Feinberg has convincingly argued, 'there are abundant reasons ... for being extremely cautious in applying the offense principle'. ${ }^{74}$

However, even notwithstanding these difficulties, the kind of offence with which the Administrative Court was concerned was of an exceptionally attenuated variety. In other words, all of the parties accepted that arrangements could have been made whereby there would have been no or very little prospect of anyone witnessing funeral pyres who did not wish to do so. Cremations would be in secluded places, out of public view, and the chance of the public "stumbling on a funeral pyre was remote [given that] sufficient signs could be

\footnotetext{
${ }^{69}$ See, generally, R Masterman, 'Section 2(1) of the Human Rights Act 1998: binding domestic courts to Strasbourg?' [2004] Public Law 725; R Masterman, 'Taking the Strasbourg Jurisprudence into Account: Developing a Municipal Law of Human Rights under the Human Rights Act' [2005] ICLQ 907; and S Foster, 'The protection of human rights in domestic law: learning lessons from the European Court' [2002] NILQ 232.

${ }^{70}$ See generally, M Hunt, Using Human Rights in English Courts (Hart, Oxford, 1999); R Clayton, 'Judicial Deference and democratic dialogue' [2004] Public Law 33; and D Pannick, 'Principles of Interpretation of the Human Rights Act and the Discretionary Area of Judgment' [1999] Public Law 545.

${ }^{71}$ Note 19 , above, at [105].

72 See M Nussbaum, 'Secret Sewers of Vice' Disgust, Bodies and the Law', in S Bandes (ed) The Passions of Law' (New York University Press, 1999), pp 19-62.

${ }^{73}$ Percy v Director of Public Prosecutions [2001] EWHC Admin 1125 at [28], (Hallett J).

${ }^{74} \mathrm{~J}$ Feinberg The Moral Limits of the Criminal Law; Offense to Others (OUP, 1985) p 25.
} 
deployed warning people of the site' ${ }^{75}$ What is more, anyone who considered such funeral rites to be offensive, and/or mourners of a 'sensitive disposition' would be free, quite simply, to absent themselves. ${ }^{76}$ The Administrative Court in Ghai was concerned, therefore, not with direct offence being caused to those observing funeral pyres with their own senses but, rather, with a secondary, or indirect, form of offence.

In this regard, perhaps one of the most problematic aspects of Cranston J's ruling was his reliance on the European Court's decision in Otto Preminger Institute v Austria, in which an anti-religious satirical film was banned by the Austrian authorities in the Tyrol region on the basis that it would be offensive to the Roman Catholic majority in the area. ${ }^{77}$ The Strasbourg Court held that the ban did not breach the right to freedom of expression under article 10 of the ECHR, since it fell within the state's margin of appreciation, even though the applicants had argued that the film would only be seen by (and therefore risk causing offence to) those who chose to see it. ${ }^{78}$ Nevertheless, the European Court held that 'there was sufficient public knowledge of the basic content of the film to give a clear indication of its nature, such that it was capable in and of itself of causing offence, even though those offended had not been to see it' ${ }^{79}$ Cranston J held that the 'same principle must apply' to funeral pyres. ${ }^{80}$ The distress being prevented was therefore not that of people witnessing at first hand burning human bodies, but rather the sensibilities of people who would find the mere idea of funeral pyres 'in and of it itself' offensive. ${ }^{81}$

Cranston J's reasoning in this regard is again open to serious question. In his work exploring the moral limits of the criminal law, Joel Feinberg argues that such attenuated forms of offence should not form the basis of criminal liability. He draws a parallel with the proposition that a ' $\mathrm{keg}$ of nails by the side of the road [is not] a public nuisance because it frightens an unduly skittish horse.' Feinberg goes on to say:

Human beings who take offence at remarkably little provocation should have the same standing in law courts as skittish horses. The most "skittish" imaginable person is he who suffers acute disgust and revulsion, shock to sensibilities, shameful

\footnotetext{
${ }^{75}$ Note 19 , above, at [108].

76 Ibid.

${ }^{77}$ Otto Preminger Institute v Austria (1994) 19 EHRR 34.

${ }^{78}$ The film could only be watched at the applicant's 'art house' cinema (which had a narrow specialist clientele), on payment of a fee by those who were over 17 years of age.

${ }^{79}$ Otto Preminger, note 73 at [53-54].

${ }^{80}$ Note 19 , above, at [120].

${ }^{81}$ Ibid.
} 
embarrassment, annoyance, frustration, resentment or humiliation not from something he sees, feels, smells or hears, but rather from unseen activities he knows or fears may be happening beyond his ken...

If "bare knowledge" that discreet and harmless "immoralities" are occurring in private leads to severe mental distress, we should attribute the distress to abnormal susceptibilities rather than the precipitating cause. We don't punish persons when their normally harmless and independently valuable (at least to themselves) activities happen to startle a skittish horse whose presence was unsuspected. Rather we expect owners of skittish horses to keep them away from "startling" activities and to take steps to cure their skittishness. ${ }^{82}$

The Administrative Court's decision in Ghai does just this - it protects the sensibilities of the most queasy, the 'most skittish' in the population at the expense of the profoundly held beliefs of the individual.

A further criticism of this aspect of the Administrative Court's approach in Ghai is that it is highly questionable whether people have the right not to be offended as asserted in Otto Preminger. ${ }^{83}$ The philosopher James Griffin, when considering the tradeoffs between human rights and other values, has argued that:

there are values such that a certain amount of the one cannot be outweighed by any amount of the other. ... it seems to me that, if what is at stake is my reasonable conception of a good life [or good death?] then no amount of mere upset and distress for members of my community could outweigh it; it would not matter if a hundred people were upset and distressed, or a thousand, or a million. ${ }^{84}$

However, even if it is conceded that such a right not to be caused offence can be derived from article 10(2) as Otto Preminger suggests, this right cannot be seen as conferring a carte blanche on states to restrict any offensive expression or conduct. ${ }^{85}$ Indeed, in Otto Preminger itself the European Court stated that the obligation on states is to 'avoid as far as possible expressions that are gratuitously offensive to others and thus an infringement of their

\footnotetext{
${ }^{82}$ Feinberg, note 70 above, at pp 33-34.

${ }^{83}$ Otto Preminger, note 73, above, at [49]. For a critique of the European Court's ruling in Otto Preminger see D Pannick, 'Religious feelings and the European Court' [1995] Public Law 7.

${ }^{84}$ J Griffin, 'First Steps in an Account of Human Rights' (2001) European Journal of Philosophy 306 at 314.

${ }^{85}$ See also R (ProLife Alliance) v British Broadcasting Corporation [2003] UKHL 23 at [123] (Lord Walker).
} 
rights' ${ }^{86}$ There seems, therefore, to be a requirement that in order for interference with freedom of expression to be justified, the offence caused to religious sensibilities must be gratuitous.

In stark contrast, the Administrative Court in Ghai accepted that the claimant genuinely believed that open air cremation was a vital part of his cycle of existence, denial of which would have 'devastating consequences' for him in the afterlife. ${ }^{87}$ On the Court's own finding, Mr Ghai could in no way be described as requiring a funeral pyre just for the sake of it, gratuitously. ${ }^{88}$ His reasons were of absolute centrality to his existence. Even if it had been accepted that others would (or could) be offended by the knowledge of funeral pyres taking place, it could not even remotely be contended that such offence would be caused 'gratuitously', a requirement which the European Court's test in Otto Preminger seems to demand.

Cranston J relied heavily on Otto Preminger in Ghai, but it is important to note that the European Court has apparently moved away from Otto Preminger in recent years. Today it is doubtful whether article 9 affords protection to one's religious feelings over and above other kinds of offence. ${ }^{89}$ Yet, even if this is not the case and the Otto-Preminger test ought to still be employed, ${ }^{90}$ there is no suggestion in Ghai that it was specifically religious feelings that were being protected. It is significant that at no point in the judgment was any attempt made to explain the exact kind of offence that the cremation ban was intended to prevent. Presumably it was just a vague sense of public disgust or queasiness at the very thought of human remains being burnt in an open funeral pyre - an example of what has been termed the 'yuck factor'. ${ }^{91}$ Yet this is surely far removed from extreme or gratuitous offence being caused to religious convictions, which was supposedly at issue in Otto Preminger. ${ }^{92}$

\footnotetext{
${ }^{86}$ Otto Preminger, note 73, above, at [49] (emphasis added). In its subsequent case law the Court has stressed that where restrictions on freedom of expression are introduced in order to prevent offence, the expression in question must be 'gratuitously offensive'. See Giniewski v France, Application No 64016/0031, 31 January 2006 (HUDOC) at [52] and Klein v Slovakia, Application No 72208/01, 31 October 2006 (HUDOC) at [51-52]. ${ }^{87}$ Note 19 , above, at [8-9].

${ }^{88}$ Ibid, at [100].

${ }^{89}$ See Giniewski v France, Application No 64016/0031, 31 January 2006 (HUDOC) and Klein v Slovakia, Application No 72208/01, 31 October 2006 (HUDOC). Moreover, Professor Luzius Wildhaber, former President of the European Court of Human Rights, speaking extrajudicially (at the University of Leicester, 18 March 2009) has suggested that the European Court would probably decide Otto Preminger differently today.

${ }^{90}$ For example, see İA v Turkey, No 42571/98, ECHR 2005-VIII [29], where the deferential approach of the European Court to religious sensibilities can be contrasted with its less deferential approach in Giniewski v France and Klein v Slovakia (ibid).

${ }^{91}$ LR Kass, 'The Wisdom of Repugnance' (1997) The New Republic, p19.

${ }^{92}$ Interestingly, other much more public, commercially exploitative and pseudo-scientific/rationalist uses of human remains have not been subject to restrictions, most notably Gunter von Hagen's 'Bodyworlds' exhibitions (in which preserved corpses are displayed like tailor's dummies), which have been shown on terrestrial British television.
} 


\section{'Engagement with the political, not the judicial, process'?}

It will be recalled that these backdrop features led directly to the Administrative Court's conclusion that this was a matter more appropriate for resolution by 'elected representatives' than a court. Consequently it was suggested that the applicant pursue his case by political rather than legal means, by lobbying and campaigning to change the legislative framework. ${ }^{93}$ Had he not succeeded at the Court of Appeal this, of course, would have been an option for Mr Ghai but clearly, given that Hinduism per se, let alone that strand of orthodox Hinduism for which open air cremation is necessary, is a minority faith in the UK, his chances of success in the would appear to have been slim.

Certainly, this is an area which demands a careful and balanced approach, with due regard accorded to cultural and religious sensitivities. It probably is the case that the best forum for ultimately striking this kind of balance act is the political. But reliance on these arguments - that the appropriate process by which this issue should be addressed was not the judicial, but the political—resulted, in Ghai, in the Administrative Court wholly failing to carry out the task of weighing the competing factors itself. It effectively abrogated its decision making power, handing it over wholesale to the elected arms of governance. This appears to come close to that very majoritarianism that the legal protection of human rights in a liberal democracy is intended to forestall.

It is perhaps a trite point, but the Human Rights Act 1998 does not give courts the power to 'strike down' primary legislation. The Act preserves the sovereignty of Parliament. Some have argued, however, that the HRA does provide the mechanisms by which a kind of constitutional dialogue may take place in which the courts are able to initiate a 'conversation' with the other arms of governance as to the precise scope and content of Convention rights. ${ }^{94}$ With this in mind, it is important to remember that even if the Administrative or the Appeal Court in Ghai had held the 1902 Act and the 2008 Regulations were in breach of Mr Ghai's article 9 rights, it would still have been for Parliament and Government to have put into effect remedial provisions, taking into account all of the factors raised. (Indeed it would have been open to them to have reasserted the ban in clearer terms - such is the consequence of the HRA's maintenance of Parliamentary sovereignty.) In all probability a finding of a breach

\footnotetext{
${ }^{93}$ Note 19, above, at [121-3] and text accompanying notes 41 and 42 above.

${ }^{94}$ The primary means by which this dialogue may take place being s 3 and s 4. See eg, Hansard, HC Vol 314, col 1141 (June 24, 1998) (Jack Straw MP, Home Secretary); T Hickman, 'Constitutional Dialogue, Constitutional Theories and the Human Rights Act 1998' [2005] Public Law 306; R Clayton, 'Judicial deference and 'democratic dialogue': the legitimacy of judicial intervention under the Human Rights Act 1998' [2004] Public Law 33.
} 
(by either the Administrative or the Appeal Court) would have led to calls for 'elected representatives' to set up a workable regulatory framework that would have afforded respect to all the competing interests, including the deeply held religious convictions of orthodox Hindus.

In contrast, however, the extremely deferential stance adopted by Cranston J would, but for the Court of Appeal's decision, have rendered any consideration by Government or Parliament unlikely, no matter what political lobbying Mr Ghai might have engaged in. Indeed, ironically, if orthodox Hindus had needed to campaign for legal reform, it seems likely that the Administrative Court's judgment in Ghai would have been used as evidence by the Government that British law was fully compliant with international human rights standards and that, as a consequence, there was no need for any change.

\section{CREMATION, CULTURE AND THE COMMON LAW}

It is worth recalling that in Mr Ghai's case, the followers of his 'strand of orthodox Hinduism, ${ }^{95}$ believe that fire is the embodiment of the god Agni, and that their failure to perform a final sacrifice to him, by way of cremation on an outdoor funeral pyre (in strict accordance with the Vedic texts), will interrupt the cycle of birth/rebirth and harm the future course of the soul, perhaps irrevocably. ${ }^{96}$ The Administrative Court agreed that the performance of anthyesthi sanskara was a manifestation of the claimant's religious belief, and accepted that it was his 'genuine belief, held in good faith' that were he not to be cremated on an open air funeral pyre there would be devastating results for him in the afterlife. ${ }^{97}$ However, and the point bears repetition, having acknowledged the absolute centrality of anthyesthi sanskara to the claimant's most fundamental beliefs, the Administrative Court then accepted the necessity of prohibiting this ritual merely in order to prevent offence to those who were not even going to witness it at first hand.

In effect the Administrative Court was saying: 'We accept that you believe this ritual is crucial to your existence; and it is certainly not appropriate for us to inquire into the validity of your belief. And when it comes to manifesting your belief, as long as it's not trivial and makes sense, we are not going to probe too deeply'. But then, at the pivotal point in its analysis, when the proportionality of the state's interference with the fundamental right

\footnotetext{
${ }^{95}$ Note 19 , above, at [101].

${ }^{96}$ Note 19, above, at [22-23].

${ }^{97}$ Note 19, above, at [93].
} 
was to be assessed, and the manifestation of Ghai's belief had to be weighed against the public good, the Court was prepared to accept that the prevention of an attenuated form of secondary offence justified the prohibition of (what it had already accepted was) a subjectively crucial sacrament.

The Administrative Court's reasoning and decision in Ghai perhaps indicate a judicial reluctance to empathise with patterns of religious unorthodoxy, and a failure to take the imaginative leap of seeing the world from the perspective of the other, especially those whose beliefs it cannot even come close to comprehending. ${ }^{98}$ As long ago as the seventeenth century, Pierre Bayle used the technique of imagining the world from the perspective of those with other faiths as a means of forcing his opponents to confront the consequences of their own intolerance. ${ }^{99}$ More recently, Conor Gearty has argued that compassion might be a term upon which our modern human rights vocabulary could be built, because compassion has 'a cognitive element (understanding the other), an affective element (feeling for the other) and a voluntarist element (doing something about the other). ${ }^{100}$ In a similar vein, Richard Rorty has argued that we need an increase in sentimental education, a need of a 'progress of sentiments' leading to 'an increasing ability to see the similarities between ourselves and people very unlike us as outweighing the differences'. ${ }^{101}$ Thus, were the Administrative Court in Ghai to have made a leap of 'imaginative identification', ${ }^{102}$ had it more obviously tried to see the universe from the perspective of the religious believer, its approach might have been very different.

Of course it must be acknowledged that matters relating to death generally and funeral rites in particular tend to be highly emotive. It is thus not difficult to see why, in areas such as these, judges proceed conservatively. However, such considerations aside, the history of the common law provides at least one pertinent example of a court displaying compassion and being willing to 'step into the shoes of the believer'. In 1884 Dr William Price a 'surgeon, healer, Druid, vegetarian and self declared infidel' was prosecuted at Cardiff Assizes for the

\footnotetext{
${ }^{98}$ See, generally, Frans De Waal, Age of Empathy (Random House, 2009) and Martin L Hoffman, Empathy and Moral Development: Implications for Caring and Justice (Cambridge University Press, 2001).

${ }^{99} \mathrm{P}$ Bayle, Commentaire philosophique sur ces paroles de Jesus-Christ:Contrains-les d'enter in Annie Goodman Tannenbaum, Pierre Bayle's Philosophical Commentary: A Modern Translation and Critical Interpretation (Peter Lang Publishing, 1987) (1727) cited in J Habermas, 'Intolerance and Discrimination', 1(1)(2003) International Journal of Constitutional Law 2 at 4-5.

${ }^{100}$ Conor Gearty, Can Human Rights Survive? (The Hamlyn Lectures) (Cambridge University Press, 2006) p 43.

${ }^{101}$ Richard Rorty 'Human rights sentimentality and rationality', available online at usm.maine.edu/ bcj/issues/three/rorty.html (accessed 4 Janurary 2010).

${ }^{102}$ Richard Rorty, Contingency Irony and Solidarity (Cambridge University Press, 1989) p 93.
} 
cremation of his five month old son, Iesu Grist (who had died of natural causes). ${ }^{103}$ The great Victorian jurist, James Fitzjames Stephen, in adjudicating on the matter, directed the jury that a person who burns instead of burying a dead body did not commit an offence, unless he acted in such a manner as to amount to a public nuisance at common law.

It is not my place to offer any opinion on the comparative merits of burning and burying corpses, but before I could hold that it must be a misdemeanor to burn a dead body, I must be satisfied not only that some people, or even that many people, object to the practice, but that it is, on plain, undeniable grounds, highly mischievous or grossly scandalous. ... There are, no doubt, religious convictions and feelings connected with the subject which every one would wish to treat with respect and tenderness, and I suppose there is no doubt that as a matter of historical fact the disuse of burning bodies was due to the force of those sentiments. I do not think, however, that it can be said that every practice which startles and jars upon the religious sentiments of the majority of the population is for that reason a misdemeanor at common law. ... Though I think that to burn a dead body decently and inoffensively is not criminal, it is obvious that if it is done in such a manner as to be offensive to others it is a nuisance of an aggravated kind. A common nuisance is an act which obstructs or causes inconvenience or damage to the public in the exercise of rights common to all Her Majesty's subjects. To burn a dead body in such a place and such a manner as to annoy persons passing along public roads or other places where they have a right to go is beyond all doubt a nuisance, as nothing more offensive both to sight and to smell can be imagined. ${ }^{104}$

Stephen J, it is submitted, hit the nail on the head. It is striking that his interpretation of the common law position is a good deal more accommodating of religious freedom than that under statute, at least as interpreted by the Administrative Court. What makes this particularly noteworthy is that the Victorian age is hardly remembered as a time of enlightened tolerance in respect of cultural or religious diversity. ${ }^{105}$ Moreover, the 'Victorian'

\footnotetext{
${ }^{103} \mathrm{R}$ v Price (1884) 12 QBD 247. Considered in Ghai, note 19, above, at [72]. The case of Price led to the movement which ended with the passage of the Cremations Act 1902, formally permitting cremation. See J Stevens Curl, The Victorian Celebration of Death (Sutton Publishing Ltd, Stroud, 2000), pp 184-6. ${ }^{104} \mathrm{Ibid}$, at 255-256 (emphasis added).

${ }^{105}$ See generally, James Moore, Religion in Victorian Britain (Manchester University Press, 1988).
} 
view of a 'good death' ${ }^{106}$ seems very different from such notions today in contemporary Britain. ${ }^{107}$ Thus, it is all the more surprising that the $19^{\text {th }}$ century common law position in respect of funeral rites appears more progressive than has (hitherto) been the case under the Human Rights Act 1998.

\section{CONCLUSION}

Herodotus, writing in the fifth century BCE, recounts a tale of Darius the Great, King of Persia:

... he summoned the Greeks who happened to be at his court, and asked them what they would take to eat the dead bodies of their fathers. They replied that they would not do it for any money in the world. Later, in the presence of the Greeks ... he asked some Indians, of the tribe called Callatiae, who do in fact eat their parents' dead bodies, what they would take to burn them. They uttered a cry of horror and forbade him to mention such a dreadful thing. One can see by this what custom can do, and Pindar, in my opinion, was right when he called it "king of all". ${ }^{108}$

As a Zoroastrian Darius knew, of course, that the only correct way to dispose of the dead was by placing the corpse on a high tower to be devoured by vultures. ${ }^{109}$

Herodotus used this anecdote to illustrate his contention that every society considers its own beliefs (and related practices) to be superior to those of others; and the fact that peoples can have such vastly differing beliefs and practices on the responses to a problem

\footnotetext{
${ }^{106}$ For example, Victorians placed great emphasis on matters such as the religious piety of the deceased: Glennys Howard, 'Is There a British way of Death', in Allan Kellehear et al, note 7, above, p 84. See also Pat Jalland, 'Victorian death in decline 1850-1918', in Peter Jupp and Clare Gittings (eds) Death in England. An Illustrated History (Manchester University Press, 1999) pp 230-255.

${ }^{107}$ Tony Walter observes that the idea of a 'good death' has changed from being dominated, in the past, by religion, to being more focused, now, on receiving medical assistance and being able to share one's experiences with fellow sufferers: Tony Walter, 'Historical and cultural variants on the good death' (2003) British Medical Journal, 327:218-220. See also, Dorothy Austin, Peter C Jupp, and Julia Neuberger, Dying Well: A Guide to Enabling a Good Death (Radcliffe Publishing, Abingdon, 2004) pp 85-122; and James W Green, Ogden Nash, Beyond the Good Death: The Anthropology of Modern Dying (University of Pennsylvania Press, 2008).

${ }^{108}$ Herodotus, The Histories (Penguin, 1996) Trans. Aubrey de Sélinourt at 169. For a discussion of a modern parallel see "'Thus Are Our Bodies, Thus Was Our Custom': Mortuary Cannabalism in an Amazonian Society"Beth A Conklin in Death, mourning and burial: a cross cultural reader, Antonius CGM Robben ed. (Blackwell, Oxford 2004) at 238.

${ }^{109}$ Mary Midgely Can't We Make Moral Judgments? (New York: St Martin's Press, 1991) at 83, cited in S Lukes, Moral Relativism (London Profile, 2008) at 28.
} 
which is common to all is evidence of the fact that that there is no morally right approach. On the contrary, the diverse practices of cultures are dictated by custom which is 'king of all'. 110

The decision of the Court of Appeal in Ghai that an outdoor funeral pyre (within a walled enclosure, open to the sun) is permitted, is good news for Hindus, Sikhs, and anyone else who wishes their mortal remains to be cremated in this way. No doubt it was with great relief that the judges in the Court of Appeal, having ascertained that such an arrangement would satisfy Mr Ghai's beliefs, were able to resolve the issue through traditional methods of statutory construction, rather than having to tussle with the delicate task of balancing the religious faith of the minority against the supposed offense caused to the sensibilities of the majority.

What is disturbing about the litigation, however, is the readiness of the Administrative Court (once it had found that the Cremation Act and associated regulations prohibited open air funeral pyres) to accept that the sincerely held religious beliefs of the individual could be overridden in order to protect the public from secondary offence, coupled with its willingness to shuffle off its decision making responsibility to the other arms of governance. There is something of an irony here. For, as we have seen, under both the common law ( $R v$ Price) and under traditional canons of statutory interpretation (the Court of Appeal in Ghai) funeral pyres were found to be permitted. But once the issue was framed in terms of human rights the claim was overridden with apparent ease. The invocation of a human right, with its associated exceptions, seems to have resulted in a weakening of protection for religious practices. Contrary to what might have been expected, the very invocation of article 9 seems to have opened up the trap of cultural relativism identified by Herodotus, in this exact context, two and a half thousand years ago; for the assumed offence of the majority was used to justify the curtailment of minority religious practice. Under the Human Rights Act it seems, where claims to religious practice that might cause offence are concerned, as the 'Father of History' put it, custom is indeed the 'king of all'.

${ }^{110}$ See note 108, above. S Lukes, Moral Relativism (London Profile 2008). 